\title{
Asymmetric Partnership: Migrant Organisations, Trade Unions and the Equality Ombudsman
}

\author{
Nedžad MEŠıĆ, Aleksandra ÅLUND \\ Institute for Research on Migration, Ethnicity and Society (REMESO), \\ Department for Social and Welfare Studies (ISV), Linköping University, Sweden \\ nedzad.mesic@liu.se, aleksandra.alund@liu.se
}

The study examines civil society agency for social inclusion among Associations Founded on Ethnic Grounds (AFEGs), focusing on their engagement for combating discrimination and enhancing migrant incorporation into the Swedish labour market. The overall rationale of the study investigates the complex institutional conditionality of AFEGs for developing their agency as social movement and civil society actors. The main aim of this study has been to understand how anti-discrimination agencies run by AFEGs, with subsidy support by the state, describe their experiences, and which implications the subsidy may have for the orientation and direction of their actions. The study comprises primarily interviews with anti-discrimination lawyers and heads of two agencies, but also interviews with representatives for the Equality Ombudsman. The greatest challenge for the agencies has been caused by subsidy cutbacks, which have affected both the working conditions of the agencies and other engagements of the AFEGs, such as educational courses among their members, awareness raising concerning the issues of anti-discrimination among different officials, in municipalities, trade unions and among employers. Due to the cutbacks, the civil society actors such as AFEGs have been forced to adapt to market principles by becoming entrepreneurs specialised, in this case, in the field of anti-discrimination law. The study further analyses the effects of this development as well as opportunity structures for collaboration with trade unions and the Equality Ombudsman. Even though these partnerships reveal relational asymmetries, the authors call attention to current and possible future openings in opportunity structures for wider collaboration between AFEGs, trade unions and the Equality Ombudsman.

Key words: social movement, labour rights, social inclusion, migrants, anti-discrimination, Equality Ombudsman, trade unions 


\section{Aims and issues}

The study examines civil society agency for social inclusion among Associations Founded on Ethnic Grounds (AFEGs), focusing on their engagement for combating discrimination and enhancing migrant incorporation into the Swedish labour market. We will use the acronym AFEG instead of "immigrant associations" as this concept has been criticised in academic debates as stigmatising, since it refers to different generations with an immigrant background in Sweden, including Swedish citizens, who are thereby regarded as outsiders. The study examines the access of AFEGs to "public voice" (Solomos, 2003) and the institutional opportunity structures for co-operation between AFEGs, public institutions and other organised interests.

Social exclusion and discrimination of migrants in Sweden has created a ground for the development of social movements of civil society, demanding change. Seeds for such movements have germinated, not least in multi-ethnic urban settings across Sweden. They provide a driving force for various types of activism, with AFEGs assuming an important role in projects for labour market integration (Ålund and Reichel, 2007), including their involvement in combating discrimination (Hobson and Hellgren, 2008). AFEGs are, in this sense, important actors in civil society aiming at social change. Yet their position and capacity for forging alternatives appear ambiguous, Ålund and Reichel (2007) argue, straddling between targeted and conditioned funding and instrumental governmental monitoring, on the one hand, and voluntary social activism with alternative agendas, organisational cultures and practices, on the other hand.

Following from this, the overall rationale of the study investigates the complex institutional conditionality of AFEGs for developing their agency as social movement and civil society actors. Earlier studies in Sweden (Ålund and Reichel, 2007) have indicated the importance of changing opportunity structures for civil agency and institutionalisation of social movements, embedded in new forms of governance based on partnership between the state, the market and civil society. ${ }^{1}$

This overall research agenda will be elucidated through a study of anti-discrimination agencies (ADA) among two national AFEGs federations. The anti-discrimination agencies focused upon in this study are each created and led by federative bodies (the FFER and SIOS associations), which

\footnotetext{
${ }^{1}$ In our approach to opportunity structure analysis we follow propositions developed by, among other, Patrick Ireland (1994), and Koopmans and Statham (2000). See also Solomos and Però (2010).
} 
organise a number of individual AFGEs. The anti-discrimination agencies can thus be viewed as specialised functions of AFEG federations. Our focus is set on the ways that ADA position themselves, harmonise and coordinate their work in relation to the financial means and conditions that are put forward by the Swedish state, when incorporating the civil society in the general exertions of countering discrimination in the labour market. The main aim is to understand how ADA accounts for the mission directed by the state and which implications the subsidy may have for the orientation and direction of their actions. The study comprises primarily interviews with anti-discrimination lawyers and heads of the two agencies, but also interviews with representatives for the Equality Ombudsman.

\section{Background}

Whereas AFEGs were primarily described in the past in relatively marginal terms as social players, with sporadic participation and with limited membership figures (Bäck and Soininen, 1996), in recent times their organisational life has developed both as regards forms and membership numbers (Aytar, 2007). They are organised as independent local entities and as individual and amalgamated confederations. The Co-operation Group for Ethnic Associations in Sweden (SIOS), one of the largest amalgamations of individual associations, organises some one hundred thousand members. The total number of members of various organisations and confederations is difficult to estimate since it is constantly changing. Nevertheless, the total number of members of national confederations entitled to receive governmental support amounted to about twice this amount, two hundred thousand (Dahlstedt, 2003).

The Swedish state has long assumed a rather paternalistic attitude towards AFEGs (Ålund and Schierup, 1991). On the other hand, the system prescribed definite organisational forms along ethnic lines and divided the "immigrant" category into mutually exclusive organisations. As the state sought legitimacy by developing a policy for diversity and integration, these very declarations, by focusing on multiculturalism in narrowly ethnic and cultural terms, seemed to lead to both ideological and political control of ethnic association activities. This fundamentally ambivalent attitude also prevented initiatives for collaboration (partnership) and mobilisation based on overarching issues like social exclusion and political marginalisation of Swedish "immigrants" (Ålund and Schierup, 1991). With time, the ethnocultural stamp has gradually come to be complemented by ever greater commitment to issues of discrimination, conditions for social citizenship, and social inclusion, which in turn is reflected in the increasingly close 
collaboration across ethnic lines and the emergence of inter-ethnic confederations and associations.

Since the 1990s, the attitude of the state toward AFEGs has gradually changed, not least as a result of the fact that the corporative elements of Swedish politics - where various organised interests, such as the parties on the labour market, had a direct influence on the political process - have largely been replaced by other forms of co-operation between governmental and non-governmental organisations. Even though there is some justification for claiming that the state still does far too little to value and promote, spotlight and acknowledge the involvement of "immigrants" in civil society (Alund and Reichel, 2005), the predominant approach to AFEGs seems to be less paternalistic than in the past. In line with integration policies of recent years, activity in associations is now seen as a valuable resource in efforts to implement integration policy.

An altered system of subsidies, oriented toward "partnership for integration", also promotes various forms of co-operation between ethnic associations, state and municipal institutions, private interests, and social movements. One of the major questions in the study is to investigate possibilities for and existence of this kind of co-operation. While several national investigations (Lappalainen, 2005; Kamali, 2006) on structural discrimination have focused on the issues of institutional discrimination, very few studies have investigated anti-discrimination agency and the role of AFEGs. In recent studies the importance of EU Anti-Discrimination directives has been pointed out as important for the development of Swedish anti-discrimination laws as well as a gap between EU legislation and implementation in Sweden. Problems discussed relate to the reluctance in public institutions in management of this legislation, the low level of political will and the lack of established legal practice (Bengtsson, 2004; Borevi, 2004; Bengtsson and Kugelberg 2009; Hellgren, 2007). A special problem is observed as dependency of voluntary organisations on public funding; top down regulation, prioritisations of gender rather than ethnic discrimination, and, particularly the effects of dependency on state funding on the NGOs autonomous political voice (Hellgren, 2007).

\section{State-financed civil society - incitements and dilemmas}

The central theoretical question is focused on institutional opportunity structures for civic agency among AFEGs. The international literature has emphasised the importance of institutional opportunity structures for organisation of AFEGs and their participation in democratic processes (e.g. Koopmans and Statham, 2000). We argue that these associations have met 
a range of obstacles due to the weakening of the welfare state, and the deregulation and privatisation tied to the neo-liberal orientation in politics and economics, which has affected the conditions for agency among AFEGs. On the one hand these associations have taken over a number of service functions from the retiring welfare state. On the other hand, their dependency on state funding has made them vulnerable to cutbacks of these resources, which induce them to become market-oriented actors. This creates new conditionalities for their function as civil society actors.

In Sweden, the social involvement of AFEGs has increased markedly in the latest decade. Their work is becoming more and more clearly oriented towards institutional collaboration (SOU, 2000:1). The clearest example of this is the great rise in engagement in educational spheres, parental cooperative day-care centres, and free schools run by AFEGs, anti-discrimination work, and other integration-related activities. This development reflects how AFEGs behave under the conditions created by the transformation of the welfare state and its ever more differentiated institutional systems (cf. Allen and Cars, 2002). In international research, this development has also been related to new forms of partnership between the state, the market, and civil society and to the role assumed by civil society organisations in the context of changes in the welfare state. As the welfare state has receded, a number of assignments have been left to the organisations of civil society, such as matters involving human rights, the fight against poverty, and conflict resolution, but also issues regarding integration, education, and citizenship (cf. Kaldor, 2003; Einhorn, 2006).

In Swedish society, too, the voluntary organisations of civil society have been referred to as an indispensable resource and "partner" to public institutions and the market in a variety of contexts when it comes to providing different kinds of welfare services. The notion of partnership has been hailed as a new form of organisation in contemporary European politics (see Pierre, 1998; Geddes and Benington, 2001). Since the 1990s, partnership has been a major component of the social policies of the European Union and in recent years has been advocated in work to end discrimination against immigrants and ethnic minorities (Soininen, 2003; Schierup, Hansen and Castles, 2006; Dahlstedt, 2009). However, the results of partnerships among migrant organisations, state, municipality etc. have come to be referred to as "conditioned" in recent research (Dahlstedt, Ålund and Ålund, 2010) and, as this study argues, asymmetric, with migrant organisations in a subordinated and dependent position.

The deregulation and privatisation of the labour market and other processes tied to the neo-liberal orientation in politics and economics 
have been connected to the current attention being paid to civil society (Kaldor, 2003). In her survey of global civil society, Mary Kaldor (2003) depicts this complexity of connecting links between the global and the local, culture, identity, economy, political conditions and practices that characterise contemporary social movements. From the very beginning, the new social movements have been a global phenomenon tied to civic awareness and spontaneous civic initiatives, including civil rights among new ethnic minorities. Kaldor (2003: 141) links the complex expressions of contemporary social movements with a development of civil society from what she calls the activist model into a neo-liberal version. In the neo-liberal version, civil society functions as a substitute for the state, which has pulled back from certain fields, and where the "domesticated" (or tamed) social movements have turned into a market of separate NGOs. These will then have been more or less institutionalised and taken over a number of service functions from the retiring state, services that encompass human rights, combating poverty, conflict resolution, training in democracy and citizenship, education, etc. This view of NGOs focuses attention on their role as key players in the concomitant expansion of market principles with the emphasis on competition and the notion of partnership between the public and the private sector (Kaldor, 2003: 127). Nevertheless, they remain value-driven organisations, as Kaldor (2003) writes, which ultimately means that it is difficult in practice to distinguish between public service and activism. While some NGOs are organised more or less as market-related (as businesses), others continue as more provisional activist groups.

The AFEGs in this study reflect to a great extent a shift from the activist model towards a market-related organisational structure. Focusing on community development, Geoghegan and Powell (2008) assert that, although social partnership offers participatory engagement, it does so only in a circumscribed manner, which intrinsically carries a risk to co-option of protest and silencing of the societal critical voice. As such, partnership comprises elements where civil society may well discard its role as a political actor; becoming instead a site and an agent of welfare state service delivery. Sidhu and Taylor (2009) assert that the Australian turn toward mandatory partnerships built on competitive contractualism can weaken earlier alliances. They portray partnership as sites of exercise of disciplinary neo-liberalism, according neo-liberal core ideas of productivity and competitiveness. Managerial obligations imposed by funding bodies to demonstrate efficiency and accountability force community service organisations to direct scarce resources and attention towards: formalisa- 
tion of operational processes, follow-ups of work conducted, effectiveness inspections and intellectual property protection. These obligations not only increase the workloads, they also imply that the survival of civil society organisations may become dependent of their abilities to adapt to neo-liberal practices. The authors conclude that civil society involved in partnership becomes disabled in its attempts to facilitate broader structural change. Even though we found similar tendencies in our study, we would like to stress the importance of proceeding with caution, in order not to fall into a far too deterministic pathway. It is clear that AFEGs and their anti-discrimination agencies vis-à-vis recent acknowledgements and current engagements can encounter newly-found negotiation possibilities and channels for co-operation with other actors of the civil society, such as trade unions, and processes where joint efforts may result in innovative approaches for a broader social change.

\section{Dependency on state financing}

Both of the anti-discrimination agencies are state financed with a projecttype funding system. Thus, being framed as projects, the agencies are required to re-apply once a year for further subsidies. The agencies are also bound to report back to state officials three times every year, with documentation in which they have to account for the activities that have been conducted during the consecutive periods. The government agency that administrates the distribution of subsidies to anti-discrimination agencies is Ungdomsstyrelsen (The Swedish National Board for Youth Affairs - a government agency that ordinarily works to ensure that young people have access to influence and welfare). However, Ungdomsstyrelsen has only recently been assigned this task. This position was held earlier by The Swedish Integration Board, which had conducted this work since 2002. When the Swedish Integration Board was dismantled in 2007, its earlier functions were transferred to other state organs.

The first distribution Ungdomsstyrelsen made was thus in 2008. The distribution of subsidies amounted in 2008 to $€ 1.5 \mathrm{MM}$, and reached 20 anti-discrimination agencies out of the 35 that had applied (Ungdomsstyrelsen, 2008). In 2009, Ungdomsstyrelsen was presented by the Swedish state with $€ 1.56 \mathrm{MM}$ to distribute, funding which that year reached 17 agencies (ADB Sweden, 2009). However, in 2010, the subsidies were substantially lowered to $€ 1 \mathrm{MM}$ and were thus only able to support the work of 14 remaining anti-discrimination agencies (Ungdomsstyrelsen, 2010). This decrease has, inter alia, led to the closing of a sister agency to one of the anti-discrimination agencies focused upon in this paper. 
The formal aim of the subsidy is directed to agencies that, on the one hand, counteract discrimination through duty-free counselling and information directed to individuals, and influence public opinion through courses and seminars, or activities that provide general information and counselling on the other (Ungdomsstyrelsen, 2010).

The majority of Swedish anti-discrimination agencies have come together and formed a "collaboratory forum" - the Swedish Anti-discrimination Agencies. Of the two agencies depicted in this paper, the FFER (Forum for Equal Rights) is a member of this network. The SIOS agency has chosen not to enter as an associate as a resort to secure the decision-making process within its own perimeters. However, both of these agencies have entered into a more regional informal network where they exchange ideas, experiences and discuss legal matters. It is worth mentioning here that the investigation work of both agencies is managed by lawyers employed by the anti-discrimination agencies themselves.

\section{Anti-discrimination agencies' contributions and resources}

The main work of the anti-discrimination agencies revolves around discrimination investigations that the agencies' lawyers conduct at their local offices. According to the FFER anti-discrimination agency, they have received 200 cases during 2009 of which 106 met the legal requirements for legal action (FFER, 2009). Many cases remain active throughout the consecutive periods. For example, during 2008, 71 cases were finalised of which 35 were opened during 2007 and one during 2006 (FFER, 2008). We found similar trends at the SIOS agency: 106 cases during 2008, and 107 during 2009 (SIOS, 2008, 2009). Cases connected to ethnicity and religion comprise more than $50 \%$ of all the cases. Out of all the cases, a third can then be connected to the labour market (FFER, 2009; SIOS, 2009).

A conspicuous part of the work being conducted at the agencies goes on preliminary investigations through which the lawyers can determine if a report could become a concrete case. This work is focused to a great extent upon informing the clients of their rights and the potencies of protection under the discrimination law. According to the SIOS agency's lawyer, their clients often lack insights regarding the discrimination law. He states: "they think that it is some general idea regarding justice, (...) they often have other expectations". We find similar tendencies, as expressed by the FFER lawyer:

There are many (...) who believe that they have experienced discrimination, which we then must investigate, but where we conclude that there has been no discrimination. (...) The majority does not under- 
stand the system and all the channels so well, and that's where we can then assist. Sometimes they only need to make an appeal. (...) If that's the case (...) we help them, too. It is not a discrimination matter but a situation where a great effort can be made if they receive support.

As we have seen, even the preliminary investigations can be time-consuming, not only in the interviews but clients may also need other forms of support that they are not able to resolve on their own. Apart from these preliminary, shorter contributions, the main efforts of the agencies are directed to interviews with the clients in order to collect the vital items of information that could lead to a concrete case. The greatest difficulty for the lawyers to create a solid case is connected with the fundamental obstacle of gathering proof. According to the lawyers, their main contribution to anti-discrimination work lies in their specialised ability to conduct indepth interviews with the clientele, work that differentiates them from the bureaucratised anti-discrimination work conducted by the Swedish Equality Ombudsman (DO). The lawyers maintain that it can be risky for people to contact the DO because of their rigid analyses of the officially received letters, and that the outcome may as well be "We do not find that this is discrimination". Contrary to the ombudsmen's work, the FFER agency's lawyer accounts for their way of handling the clients:

You can imagine if one barely masters the language (...). What is important in our meetings (...) is that they can talk openly. I dare to maintain that 70-80 percent of the opening statements are a pure relief valve. (...) which very often leads - let's say in a meeting of 50 minutes - that is, it is in the last 15 minutes that I may get the most important, the core, which works juristically.

In order to arrive at this point where the person manages to provide an account of experiences that can lead to juridical intervention, the lawyers have to rely to a great extent on their personal emphatic abilities.

In the beginning one mostly sits there and confirms that it is terrible, frustrating and of course one reacts, it is some pretty horrible stuff, and one gives tips and advice sometimes, gets a tissue if they start to cry and so on. However, even though one is performing this therapeutic function, one sits and waits for the right moment to start asking questions for these prerequisites. (...) I have even had cases when the last five minutes, yeah, yeah, and I feel no, no, there is no discrimination (...) and then in the last five minutes they say: "they said this, and this, and this", (...) it is what determines the whole case. That would have been missed by the DO because they do not have 50 minutes to set aside. 
The FFER's head maintains that their uniqueness in this way of operating is crucial for their survival. "And we want to maintain our distinctiveness, if we don't come through with that we will soon be shut down."

A great deal of the lawyers' work is also directed towards helping the clients to structuralise their documents. Clients are often poorly prepared and lack the insights in the case-building process. The SIOS agency's lawyer gave an account of this work: "From the beginning it is often so that they tell you, (...) it comes in scenes, randomly so to say. (...) then one needs to explain to them you firstly have to put everything in the right order". The work is time- consuming and dynamic. Some investigations take 15 minutes, others more than a year. The juridical investigation is often not confined to a single situation, but rather intertwined with constantly occurring incidents. The FFER agency's lawyer asserts that it is therefore very important for him to have a close relation to his clients, a situation in which he further maintains that his own Latin/immigrant background can carry bounding functions in the interactions with immigrants, especially the Spanish-speaking ones.

The legal processes that the agencies conduct are commonly directed towards the creation of structuralised cases that can be presented to the DO. However, few cases ever reach the DO in the end - because such action is not always preferred by the clientele. According to FFER, the legal processes most commonly lead to legal conciliations between those involved. The lawyers at both agencies explain that this process often results in solutions where the client is satisfied. The conciliations that are reached can range from apologies from the employer, to redundancy terminal payments up to 18 months, but also pure economical compensations, in one case $€ 4,470$. Another outcome can also be the retainment of an earlier employment or offers to assume a new position within a company. Apart from the investigations, legal conciliations and forwarding of cases to the DO, the agencies also take part in preventive measures. This work is often constituted of different adhoc collaborations, but also lectures and arrangement of workshops and seminars targeting schools, employers, trade union representatives and municipalities.

A prominent and constantly recurring narrative in the interviews revolves around the question of resources. Both agencies have been affected to various extents by the latest cuts in subsidies. For SIOS, the budget cuts have led to the closing of one of their anti-discrimination agencies, which has thus contributed to great increases in workloads for the remaining agency. The agency's lawyer explains: 
Now we have an inferior operation. (...) Less people who do the work and more work to do. (...) The investigations decline in quality, one has not the time. I'm only a human being, (...) simply, more people don't get help (...) even in the cases where no formal discrimination has occurred (...) discrimination occurs that is immoral. (...) Earlier when I had more time I could do something anyway. (...) But, nowadays, in principle, one only says no to the persons that one sees are not covered by the law.

Furthermore, the lawyer maintains that this trend damages the wider purpose of the work the agencies should be conducting. When the focus is set only on the accumulation of formal legal cases, the work on general engagement and the raising of awareness regarding rights is bound to fall behind. Similar experiences can be distinguished at the FFER agency. Since the latest cutbacks in subsidies, the FFER has been forced to limit the working hours for their lawyer to 75 percent employment. Nonetheless, the lawyer states that the number of cases has remained the same, thus forcing him to work overtime with compensatory leave for overtime done. However, he states that the amount of work does not allow him to make use of the compensation. "When can I take them (the extra hours), who will suffer if I disappear for four weeks? (...) If I were strictly to keep to my 75 percent, our organisation would become deficient (...). Many cases demand the time they demand for them to be conducted decently."

He further asserts that it has been this way for all the lawyers who have worked earlier for the agency. "In the end it means that they have worked for free for a great period of their time." However, the lawyer is not the only one who has been affected; the head of the agency, too, has had to lower his working hours by fifty percent. He explains:

We had to secure (...) the vital functions of advice and support (...) but my time that would have gone to educative efforts and information disappears to a great extent. The half employment that is left goes to administrating the whole organisation. Our colleagues used to say: "Half of your time goes to administrating yourself". That is because Ungdomsstyrelsen has high demands, we report three times a year, that's the organisation part. Then the economics must be reported, then we have to take on all sorts of collaboration, so it's huge pressure. (...) we have deadlines; if we don't deliver then we won't receive a second payment.

Both agencies also give accounts of the relation between resources and the employed lawyers. The unsteady situation has been shown to lead eventually to lawyers resigning. Due to lower pay in comparison to the 
labour market in general, the lack of advancement possibilities within the organisation and the overall uncertainty, the lawyers within the agencies sooner or later move on, working within the agencies for no longer than two years. This situation affects the organisation significantly, not only because of the time it takes for a new lawyer to get settled and accustomed to the work in general, but also because the former lawyers take important experience along with them.

A positive development for the agencies has been the changes in the Swedish discrimination law, which has given non-profit associations the possibility to represent individuals in courts (Diskrimineringslag, SFS 2008:567). However, in the case of anti-discrimination agencies, this possibility lies beyond the horizon of realisation for the present. Currently the agencies do not have the means to go to court; if they were to lose a single case they would, according to the FFER agency lawyer, risk their whole organisation.

(...) no matter how good a case we have, it is impossible to know the outcome. (...) If we were to lose, and had to pay out three or four hundred thousand SEK ( $€ 33,550$ / 44,700) for legal costs to the other party, then the whole organisation would go up in smoke.

Nonetheless, this is a direction the FFER would like to take. However the fund that the agency is currently building up for such future actions serves today only as a security buffer in the case of the agency being closed down. This buffer, built up only by the scarce income from lectures and other activities, would be used in such a case to regulate the payment of salaries for the employees. This is the only income that the agency can put aside. However, according to state regulations, income must be invested in operational work. The FFER's managing director spoke about this situation, saying:

It is a huge problem. We are a project, we do not know if we will receive funding or not at the end of December. The decision regarding continued funding arrives only in February. (...) in theory, we have to discharge everybody in November and let the period of notice run out.

For now, all plans for expansion and development of their genuine engagement have had to be put aside in order to guarantee future subsidies. The formal funding conditions have forced the agencies to assume a more passive role in their anti-discrimination work. Focus has been put on securing funding and the protection of the core servicing functions. We will return to this subject in the last segment of the empirical accounts, where we will relate questions regarding the funding to a conspicuous marketisation of the work being conducted at the agencies. 


\section{The relation to the Swedish Equality Ombudsman (DO)}

The general picture of the relations to the DO is mediated through positive statements. The personnel at the agencies state that they have wellestablished collaboration with the lawyers working at the DO. They further maintain that the DO has welcomed the agencies as collaboratory partners and met them with respect. "The ombudsman has really seen us as a collaboratory partner, not an apprentice, or someone that needs to be looked after. (...) One could say that we are colleagues to them" the FFER lawyer explains. Nonetheless, the agency personnel differentiates their work from the work being conducted by the DO. The head of the FFER explains:

Our assignment is to offer advice and support, the DO's duty is to monitor whether the law has been violated. But, we are always interested in helping the client, and we would prefer to do that fully in that way, before a case needs to go to the DO.

Currently, when the agencies encounter tougher cases that cannot be resolved through negotiations, they then focus on conducting thorough investigations, which can be handed over to the DO. The agencies also handle the reverse situations where the DO redirects people to the local agencies, expecting them to conduct investigations that can structure and strengthen the cases. In some cases, the agency may be forced to redirect the client back to the DO, if they find that the case demands significant resources. In those cases, the head of the FFER explains that they feel pressured to give adequate explanations if they cannot take on a case. It seems, despite the stable relations established with the DO, that local anti-discrimination agencies sense the need for acting with caution when dealing with the DO in order not to damage their reputation. "It has never been that laymen have called the DO and, so to say, started to handle a certain case; in that sense we have in no cases damaged our good name in regard to the DO by sounding non-professional." Even though the DO does not decide over their subsidies, the agency is careful in dealings with the DO. In the sense that when the state is the one that decides in the end over the future of the anti-discrimination agencies that they must always be cautious when having to deal with the state's institutions. A question that is important here is how this relationship, built on an asymmetrical foundation, might affect the directions and engagements that the local anti-discrimination agencies would prefer to undertake. We will try to approach this question and provide some answers to it in the final segments of this paper.

Besides, the contacts and collaboration with the DO concerning the investigational work on concrete cases, collaboration has also been established in the general work on raising awareness. The head of the FFER 
explains that trust has been built up between the local agencies and the DO. "I cannot recall that they have thought; would you like to have an education that we can offer, rather it's constantly: What can we do together?, How can we develop the collaboration?" One example of this collaboration has been the co-operation that the DO and the agencies have had during the Stockholm Pride Festival. The agencies express gratitude regarding this development and are pleased with the way the collaboration is proceeding; nonetheless, they still feel that the DO could do more in promoting the agencies' work. The FFER head explains:

I think that they could promote us in a very different way so that we could take part of the legitimacy that the authority possesses. (...) We have had cases (...) where we may have had decisive impact on their solution in a decent way, without even having been mentioned at all, and that is truly a pity. For one could have said: "With support or contribution from, with help of. . .", and so on.

Apart from these points, a further development for the local agencies is that the DO has provided them with premises for important meetings. This gesture has been widely appreciated due to the fact that both of the agencies have access only to their own local offices covering no more than twenty square meters.

The relation to the DO is mediated in a twofold way. The general picture speaks of a development that is positive for the work the agencies conduct. They are able to find channels for sustainable collaboration that contribute to the work of both actors. However, the moral of the Aesop's fable the Lion and the Mouse, that "little friends may prove great friends" echoes repeatedly in the FFER agency's narrations. The agency sees itself as a vital actor, being able to provide noteworthy services to the DO; nonetheless, they express a sense of deference due to fact that the DO is part of the state, but nonetheless an important and powerful actor that could do more to acknowledge the local agencies' potency and contributions.

\section{The relation to trade unions}

The narratives of the anti-discrimination agencies regarding their interactions with trade unions mediate tangible ambivalences. In cases connected to employment and discrimination, in comparison to the DO or the anti-discrimination agencies, the Swedish trade unions have a superior and statutorily prescribed position in taking legal action. In reference to the Employment (Co-Determination in the Workplace) Act (1976:580), the Discrimination Act (Diskrimineringslag, SFS 2008:567) lays down that the DO 
or the anti-discrimination agencies are approved to plead the subject's cause in work-related cases solely when the trade unions have declared that they will not be doing so. The anti-discrimination agencies have therefore been bound to redirect the client to her/his trade union before initiating their own investigations. However, the anti-discrimination agencies' lawyers state that it is not uncommon that their clients already are or have been in contact with their trade union, but that they are unpleased due to having been met with indifference or disloyalty on the trade union's part. The SIOS agency lawyer explains:

Oftentimes, people are very angry with their trade union when they come to me, when something has happened, something has not worked. Sometimes they come to me first; they don't even contact the trade union, but that doesn't work either. (...) The client may often perceive their trade union as being on the employer's side. (...) it occurs that the person is dissatisfied and doesn't want to have it (the case) there anymore.

In these situations, the SIOS anti-discrimination agency has sought to take on a mediating role by contacting the trade union in order to seek alternative solutions, such as to suggest that the trade union provides a different representative in the matter. The case can then, according to the lawyer, gain new momentum, whereupon the representative may give more attention to the case when being scrutinised by someone from outside the organisation. He also implies that the reactions from the trade unions upon being contacted by the agency, are positive for the most part, due to SIOS's reputation and former collaboration with the trade unions.

However, the experience of having to deal with the trade unions at the FFER anti-discrimination agency carry still more unenthusiastic undertones. The FFER agency's lawyer describes his encounters with trade unions as follows:

They are not easy to collaborate with. They are closed. (...) When one offers support in discrimination cases they are rather uninterested, generally speaking. (...) A great problem is that they are only interested in the work-legal questions.

The lawyer's further interpretation is that discrimination is a rather new task for the trade unions and that they therefore tend to neglect discrimination issues. The lawyer makes the claim that the trade unions generally focus more instead on the collective rights, which are secured by the labour-law. The lawyer discussed one of these experiences, where the trade union had missed the discrimination issue completely in a case where a company was laying off workers: 
So they had totally missed that this could be a way of discriminating, a disguised way in accordance with MBL (the law on co-determination at work) (...), but which went against the Discrimination Act. And when I had presented it and put it forward in this way, she (the trade union representative) said: "Oh my, I have to call our superior, centrally, so that she can make an assessment of this".

Similar experiences of the FFER agency have thus led to low expectations for negotiation and collaboration with the trade unions. The head of the FFER elucidates further on their stance towards the trade unions:

Oftentimes, unfortunately I have to say, the trade unions have been a burden. It has mostly been so that we have had to tell the client that we don't have any greater expectations from the trade union, but that we have to talk to them if we eventually have to report to the DO, (...) and let us get this over with as soon as possible so that we can get a "no" from them, so that we can handle it ourselves or let the DO take care of it.

$\mathrm{N}$ : So you expect a "no"?

That's what is so sad, well the trade unions would have everything to gain in having good collaboration with us, let us know what they know, and what they want so that we can also tell our client: "If you had been in a trade union, then you would have had very good and much greater support".

Due to all of these difficulties in collaboration with the trade unions, the standard line of conduct from the FFER has been to initiate parallel investigations in order not to lose time if the trade union say no to further investigation. Thus, the agency functions as a guarantor for the client's legal right to try his or her discrimination claims. However, there are also exceptions which diverge from these ambivalences. The agency has managed to establish collaboratory channels to the syndicalist trade union, SAC. SAC can be differentiated from other trade unions, both by its structure and approaches in general. Contrary to other Swedish trade unions, this trade union has taken a stand against collective agreements that exempt the trade union from the obligation to maintain peaceful relations with employers. The FFER agency's narratives mediate a mutual collaboratory engagement in the clients' discrimination claims. According to the agency, this collaboration has resulted in a number of successful investigations and legal outcomes. Their experiences of SAC resonate with openness from the trade union, which invites deeper collaborations. The agency's lawyer describes this relationship: 
They acknowledge us as a competent actor in the discrimination field and they are not afraid for us to go in and assist their client and our client (...). They are not afraid, they are so secure in this collaboration that they simply allow us to carry the discrimination question in their name. "Our member would like you to assist him or her in the negotiations, can you do that? And it's a golden opportunity for us. This is something (...) which seems only to get better..."

This collaboration seems to be deepening even though it is not built on a formalised platform. The agency and the trade union support each other in the investigations and, according to the FFER agency, are thus able to strengthen the cases better and faster than on their own. According to the agency's lawyer, this collaboration is not only facilitating the investigations but also bringing about educative effects for the trade union, which may attain preventive results in the future. The clearest difference in comparison to other trade unions is that the SAC initiates the contact with the agency when they encounter discrimination matters. The agency's lawyer clarifies:

Above all they are not afraid about this, that the individual would undermine the collective, or that we would in some way bust in and take over their area. They don't seem to have that viewpoint at all, thus enabling us to work without prejudice (...). We work on exactly the same matters; the difference is that we can use the entire trade union's power in a negotiation.

Nonetheless, the agencies' experience, in general, speak of a strained engagement on the part of the trade unions in taking on discrimination issues, a situation which has forced the agencies to adopt various strategies for dealing with the trade unions. However, it has been possible to establish collaboration that has proved fruitful in the work against discrimination. The last example shows that co-actions between a new social movement such as the anti-discrimination agencies and an old one such as the trade unions may be rewarding for the protection of citizens' right against discrimination in the labour market. However, the general picture speaks of rigid structures within the conventional trade unions, a circumstance which is not only mentioned by the anti-discrimination agencies. The DO has also observed that the trade unions need to take a clear step forward in the anti-discrimination work - a conclusion which, according to an investigator at the DO, has led them to make this issue a first priority for the next one and a half years. Furthermore, the DO has expressed in a public communication that the trade unions, as one of the focal actors, not only have a possibility, but have also a responsibility to 
act both centrally and locally in anti-discrimination issues (DO, 2010a). According to the DO, the fight against discrimination lies primarily in the hands of the employer, but also to a large extent in collaboration with the trade unions; they maintain that the parties have been modest in their work thus far (DO, 2009a). In another communication, the DO calls attention to the trade unions' role and states that "the trade unions hitherto have remained utterly passive" in pushing forward anti-discrimination activities (DO, 2009b). What the DO wants to see is that the employers and the trade unions try to solve these issues with the use of collective agreements. By taking this stand, they assign the trade unions the crucial role in the future development of anti-discrimination measures. They have however acknowledged that the trade unions need support in this field, and have thus decided to intensify their work for support of the trade unions' needs by developing tools that can prevent and counteract discrimination (DO, 2010b).

The latest development in the work of trade unions has been a central conference arranged by the TCO (The Swedish Confederation for Professional - "white collar" - Employees) where these issues have been raised and framed as a core assignment for the trade unions for the time ahead. However, the results of these aspirations remain to be seen. For now at least, these matters remain only as a forthcoming research question.

\section{Marketisation and shift of focus}

Just as earlier described, the latest cutbacks in subsides have had a great affect on the work the agencies conduct. However, the implications of the financial drawbacks have not only contributed to greater workloads, they have also led to a shift in focus from the earlier wider aim of spreading knowledge regarding discrimination in a more equal combination with the investigations, to a predominating focus on servicing the clientele. One immediate reason for this has been, of course, the cutback in subsidies; however, the FFER agency's head also explains that an earlier requirement from the Ungdomsstyrelsen to engage in educational and awareness raising work has been given a lower priority since 2009 .

These developments have thus forced the agencies to limit their wider ambitions in order to guarantee the core-function of investigation work. The head explains that other important areas of their work have suffered greatly, "we cannot go out and lecture as much as we would like, we cannot keep educating as much as we would like, and we cannot start projects". He further explains that this situation also has affected relations 
with the other agencies. According to him, there was fairer competition between the agencies before the subsidies were lowered, whereby the agencies that showed good results could be rewarded without affecting other subsidised agencies. But now, this competition has reached a new level, making the agencies fight for their survival. He further clarifies the situation:

We are far too few (agencies), and we have joined this network to collaborate in order to preserve all the agencies that are there, because they are needed, and also to raise the quality. Because we know that when one agency performs badly it usually stains the rest of us, so to say. But when they have been scratched we haven't as a matter of fact gone in and, so to say, defended the agencies (...), we do not have the energy and time.

The FFER's lawyer acknowledges that the latest developments have led to a challenging situation for his agency's work. He explains that he is unable strictly to keep to the $75 \%$ he is paid for because the quality in his cases would decrease. A further apprehension of his is that this would also then result in poorer documentation being sent to Ungdomsstyrelsen. If the rate of cases handled or the results of successful negotiations were to decline, he fears that his agency would receive subsidies reduced even further, or even be closed down.

If we report that it has become worse, which would be the consequence if we reduced our... then it wouldn't look good in the report. (...) then there is less reason to give us means in the future, we may even risk to become one of those who become kicked out, so we fall into a fox trap. The means go down but we have to keep the equally good and qualitative work in order to make it.

He states that survival is the reason for this notable competition - thus, a state of affairs which rests on an "eat or be eaten" logic. A further challenge for the agency and their only perceived last resource is to engage in a change of their ways of conduct by getting paid for their educational contributions. This is, nevertheless, an action which they are permitted to initiate according to Ungdomsstyrelsen, as long as the financial contributions are not withdrawn from the organisation. The lawyer expounds on his agency's hesitancy in this matter:

We have never presumed ourselves to be an entrepreneur, that is, someone who sells a service. We are in that phase now where we more or less, because of this, are about to become forced to be more businesminded, which rhymes very badly with the fact that we ultimately are a non-profit organisation. 
Even though the agency was created, among other reasons, to engage in open collaboration with the rest of society, we can see in the interlocutors' statements how these engagements become transformed into more markettied aspirations. Although the agencies were built on an original idea for engagement, they steadily convert to more market-tied commitments in order to secure their survival. At the same time, when the focus is primarily concentrated on the deliverance of cases, along with lower financial support by the state, there is a great risk that the quality of the investigatory work may decrease and that the anti-discrimination agencies narrow their support to other important actors in the labour market, by phasing out collaboration that does not result in financial contributions. However, this also means that if the agencies do not learn how to make this transition to marketisation, their role might well be reduced from offensive and preventive action to a reactive and passive approach to discrimination.

When it comes to the selling of services, both of the anti-discrimination agencies are enthusiastic when speaking about their specialised services and successful financial transactions. The SIOS anti-discrimination agency's lawyer explains how this side of his work is conducted:

It's a part of my employment, educational work. We offer custom-made and other courses for whoever is interested in discrimination issues. (...) When we contact a municipality we try to sell a course series which, for example, we have had with a couple of municipalities. (...) Then one sits down and compiles a course. (...) then, one often agrees on a price, because sometimes one cannot get money when it comes to schools (...). But we still try to stress that it is important, because we... Every time I walk out and spend time on this here, well, time is taken from the concrete matters.

The FFER agency also speaks of similar ways of conduct:

This year we have arranged many courses and we have been successful in being paid for them. (...) Well, in the beginning, we were receiving a certain sum and we realised that all the counterparties were surprised how cheap it was. Then we realised (...) we were way under what readers usually take. (...) We are a non-profit organisation, we are a human rights organisation, but the circumstances force us slowly but steadily to take in business considerations. Well, we have become - how to express it - business-minded in sections of our organisation and it is not the easiest thing because, in part, we do not want to charge. We wish that we could do all of this stuff without compensation, but we are forced to take compensation. I mean, I will not lay down the work for a half day here in the agency with all that 
it involves by, so to say, doing something without it being compensated, it's cost, it's our costs.

It is important to acknowledge that this has been a development over time. When the agencies entered the subsidy system, other more genuine ideas laid the ground for their engagements. What we can see is that the state subsidised funding has, with time, partly transformed the civil actors into small businesses, which function as a service for the EU pressures that have been put on the Swedish state in the field of discrimination law.

\section{Conclusion}

The work conducted by the anti-discrimination agencies rests to a great extent on their closeness to the community and their abilities to create confidence at their meetings with clients. This approach has allowed them to help those clients who are in search of justice but do not want to make their claims into a bigger matter. Even though cases have been sent to the DO to handle, many of the clients have been modest in their claims, pursuing only what they think is rightfully theirs.

The greatest challenge for the agencies has revolved around the issue of resources. The latest cutbacks have forced the agencies to secure the vital function of servicing the clientele and have thus affected other engagements that the agencies value. Moreover, the lowered subsidies, along with the focus by Ungdomsstyrelsen on concrete cases, have put strains on various collaboratory engagements. This has been especially noticeable in the area of awareness raising through education for municipalities, trade unions and employers. The agencies have been forced to place a stricter focus on getting paid for their educational services. Thus, these local anti-discrimination agencies, sprung out of the civil society, have been forced to adapt to market principles. It is absolutely clear that the agencies try to compensate for the lost full funding that they need to accomplish proactive engagements. What we see is a partial transition of the agencies' organisation towards becoming small entrepreneurs specialised in the field of discrimination law. It is nonetheless important to point out that this is a shift that occurred after the agencies began to be granted subsidies, in other words, vis-à-vis the state subsidies for partnership with the civil society, the agencies have begun, in parts of their organisation, to adapt to neo-liberal principles. If the anti-discrimination agencies, as actors of the civil society, are to be continuously viewed as partners by the state for their genuine engagements and specialised local knowledge, then they must be recognised accordingly. One way to do that could be to 
change the system of funding from project to organisation funding. Otherwise, there is a great risk that the agencies may become reduced to being only suppliers of standardised, market-dependent services, in strained relations with other actors within the field.

Even though we have illuminated in this study experiences of strained relations with the trade unions, we would like to emphasise that we also see current and possible future openings in opportunity structures for wider collaboration vis-à-vis the civil society. Negotiation possibilities with trade unions due to earlier collaboration prevail as grounds for gaining momentum for the protection of clients, other experiences speak of stable and developing collaboration with at least one trade union where joint efforts have contributed to the work of both actors in their work for securing the clients/ members right not to be discriminated. Future research questions that remain to be investigated are: In what way could the newly declared focus on discrimination issues by the trade unions affect opportunity structures for collaboration between trade unions and AFEG's? Could social movement unionism begin to take shape in this field and possibly become a channel for social change? Furthermore, it remains to be seen if the contemporary focus by the DO on the importance of trade unions in the field of antidiscrimination work, along with the developments of collaboration between the DO and the anti-discrimination agencies, invite even broader collaboration between the state and the actors of the civil society. For the present, both limited possibilities and possible openings for wider collaboration can be distinguished, and it is therefore impossible to predict either pessimistic developments or promising opportunities. It remains to be seen how the state and the actors of the civil society in the field of anti-discrimination work will proceed from this shifting point.

\section{REFERENCES}

ADB Sweden (2009). Annual Report, Sveriges Antidiskrimineringsbyråer.

Allen, Judith and Cars, Göran (2002). "The Tangled Web - Neighbourhood Governance in a Post-Fordist Era", in: Göran Cars, Patsy Healey, Ali Madanipour and Claudio de Magalhães (eds). Urban Governance, Institutional Capacity and Social Milieux. Aldershot: Ashgate, pp. 90-105.

Aytar, Osman (2007). Mångfaldens organisering: om integration, organisationer och interetniska relationer i Sverige. Stockholm: Sociologiska institutionen, Stockholms universitet.

Bengtsson, Bo (ed.) (2004). Föreningsliv, makt och integration: rapport från Integrationspolitiska maktutredningens forskningsprogram. Stockholm: Fritzes offentliga publikationer. 
Bengtsson, Bo and Kugelberg, Clarissa (eds) (2009). Föreningsliv, delaktighet och lokal politik $i$ det mångkulturella samhället. Malmö: Égalité.

Borevi, Karin (2004). "Den svenska diskursen om staten, integrationen och föreningslivet", in: Bo Bengtsson (ed). Föreningsliv, makt och integration: rapport från Integrationspolitiska maktutredningens forskningsprogram. Stockholm: Fritzes offentliga publikationer, pp. 31-63.

Bäck, Henry and Soininen, Maritta (1996). Invandrarna, demokratin och samhället: om invandrarnas politiska deltagande $i$ dagens Sverige. Göteborg: Förvaltningshögskolan, Göteborgs universitet.

Dahlstedt, Inge (2003). "Invandrarorganisationer i Sverige”, in: Flemming Mikkelsen (ed.). Invandrerorganisationer i Norden. København: Nordisk ministerråd, pp. 27-94.

Dahlstedt, Magnus (2009). “The Partnering Society: Governmentality, Partnerships and Active Local Citizenship", The Open Urban Studies Journal, 2: 18-27.

Dahlstedt, Magnus, Ålund, Aleksandra and Ålund, Anna (2010). "Villkorat partnerskap: Demokrati och social inkludering i relationer mellan bildningsförbund och föreningar bildade på etnisk grund", Dansk Sociologi, 21 (4): 75-94.

Diskrimineringslag, SFS 2008:567.

DO (2009a). Parterna måste ta sitt ansvar, Krönika om parternas ansvar att samverka om aktiva åtgärder för att uppnå lika rätigheter och möjligheter $i$ arbetslivet. http://www.do.se/Press/Debattartiklar/Parterna-maste-ta-sitt-ansvar (04.06.2009).

DO (2009b). Arbetsgivare och fack ska motverka diskriminering $i$ arbetslivet, Genmäle till artikeln "Ledarskapsproblem på universitet sopas under mattan". http://www.do.se/Press/Debattartiklar/Arbetsgivare-och-fack-ska-motverka-diskriminering-i-arbetslivet (08.12.2009).

DO (2010a). Aktiva åtgärder $i$ arbetslivet - För lika rättigheter och möjligheter. Handledning, Ödeshög: Tryck Danagårditho.

DO (2010b). DO tar krafttag mot diskriminering i arbetslivet, Public Communication. http://www.do.se/sv/Om-DO/Nyheter/DO-tar-krafttag-mot-diskrimineringi-arbetslivet (02.07.2010).

Einhorn, Barbara (2006). Citizenship in an Enlarging Europe: From Dream to Awakening. Houndmills: Macmillan. doi:10.1057/9780230502253

Employment (Co-Determination in the Workplace) Act (1976:580).

FFER (2008). Annual Report, Forum för Lika Rättigheter.

FFER (2009). Annual Report, Forum för Lika Rättigheter.

Geddes, Mike and Benington, John (eds) (2001). Local Partnerships and Social Exclusion in the European Union: New Forms of Local Social Governance? London: Routledge.

Geoghegan, Martin and Powell, Fred (2008). "Community development and the contested politics of the late modern agora: of, alongside or against neoliberalism?", Community Development Journal, 44 (4): 430-447. doi:10.1093/cdj/ bsn 020

Hellgren, Zenia (2007). "Att överbrygga klyftan mellan lag och handling: antidiskrimineringsorganisationernas verksamhet och allmänhetens ansvar”, in: Tom 
R. Burns, Nora Machado, Zenia Hellgren and Göran Brodin (eds). Makt, kultur och kontroll över invandrares livsvillkor: Multidimensionella perspektiv på strukturell diskriminering $i$ Sverige. Uppsala: Acta Universitatis Upsaliensis, pp. 411-435.

Hobson, Barbara and Hellgren, Zenia (2008). "Gender and ethnic minority claims in Swedish and EU frames: Sites of multilevel political opportunities and boundary making", in: Silke Roth (ed.). Gender Politics in the Expanding European Union: Mobilization, Inclusion, Exclusion. Oxford and New York: Berghahn Books, pp. 211-236.

Ireland, Patrick (1994). The Policy Challenge of Ethnic Diversity: Immigrant Politics in France and Switzerland. Cambridge, Mass. and London: Harvard University Press.

Kaldor, Mary (2003). Det globala civilsamhället. Göteborg: Daidalos.

Kamali, Masoud (2006). Utredningen om makt, integration och strukturell diskriminering. Den segregerande integrationen: om social sammanhållning och dess hinder: rapport. Stockholm: Fritze.

Koopmans, Ruud and Statham, Paul (2000). "Migration and Ethnic Relations as a Field of Political Contention: An Opportunity Structure Approach”, in: Ruud Koopmans and Paul Statham (eds). Challenging Immigration and Ethnic Relations Politics: Comparative European Perspectives. Oxford: Oxford University Press, pp. 13-56.

Lappalainen, Paul (2005). Det blågula glashuset - strukturell diskriminering $i$ Sverige. Stockholm: Fritzes offentliga publikationer.

Pierre, Jon (ed.) (1998). Partnerships in Urban Governance: European and American Experience. New York: St. Martin's Press.

Schierup, Carl-Ulrik, Hansen, Peo and Castles, Stephen (2006). Migration, Citizenship, and the European Welfare State: A European Dilemma. Oxford: Oxford University Press. doi:10.1093/0198280521.001.0001

Sidhu, Ravinder Kaur and Taylor, Sandra (2009). "The trials and tribulations of partnerships in refugee settlement services in Australia", Journal of Education Policy, 24 (6): 655-672. doi:10.1080/02680930802669326

SIOS (2008). Annual Report, Antidiskrimineringsbyrån Stockholm Syd.

SIOS (2009). Annual Report, Antidiskrimineringsbyrån Stockholm Syd.

Soininen, Maritta (2003). "Exploring EU ethnic diversity and anti-discrimination policy", in: Emrehan Zeybekoğlu and Bo Johansson (eds). Migration and Labour in Europe: Views from Turkey and Sweden. Istanbul: Marmara University and Stockholm: National Institute for Working Life, pp. 29-46.

Solomos, John (2003). Race and Racism in Contemporary Britain. Third edition. London: Palgrave Macmillan.

Solomos, John and Però, Davide (2010). "Introduction. Migrant Politics and Mobilization: Exclusion, Engagements, Incorporation", Ethnic and Racial Studies, 33 (1): 1-18. doi:10.1080/01419870903418944

SOU (2000:1). En uthållig demokrati! Politik för folkstyrelse på 2000-talet. Demokratiutredningens slutbetänkande. Stockholm: Fritzes offentliga publikationer. 
Ungdomsstyrelsen (2008). Antidiskrimineringsverksamheter (byråer) som får stöd under 2008 (Public Communication).

Ungdomsstyrelsen (2010). Stöd till verksamheter som förebygger och motverkar diskriminering 2010 (Public Communication).

Ålund, Aleksandra and Reichel, Isak (2005). "Medborgerlig agens för social inkludering”, in: Magnus Dahlstedt and Fredrik Hertzberg (eds). Demokrati på svenska? Om strukturell diskriminering och politiskt deltagande. Stockholm: Fritzes offentliga publikationer, pp. 231-260.

Ålund, Aleksandra and Reichel, Isak (2007). "Civic agency, market and social inclusion: The emergence of informal economy in the context of Swedish associations established on ethnic grounds", in: Erik Berggren, Branka LikićBrborić, Gülay Toksöz and Nicos Trimikliniotis (eds). Irregular Migration, Informal Labour and Community: A Challenge for Europe. Maastricht: Shaker Publishing, pp. 314-332.

Ålund, Aleksandra and Schierup, Carl-Ulrik (1991). Paradoxes of Multiculturalism: Essays on Swedish Society. Aldershot: Avebury.

\title{
Asimetrično partnerstvo: migrantske organizacije, sindikati i pravobranitelj za ravnopravnost
}

\author{
Nedžad MEŠıĆ, Aleksandra ÅLUND \\ Institut za istraživanje migracija, etničnosti i društva (REMESO), Odjel za \\ društvene znanosti i studij socijalnog rada (ISV), Linköpinško sveučilište, Švedska \\ nedzad.mesic@liu.se, aleksandra.alund@liu.se
}

U radu se istražujuje sposobnost djelovanja civilnoga društva vezanu uz društvenu uključenost unutar Udruga organiziranih na etničkoj osnovi (AFEG), a naglasak je na njihovu zalaganju za borbu protiv diskriminacije migranta i za poticanje uključivanja migranata na švedsko tržište rada. U središtu je istraživanja složena institucionalna uvjetovanost AFEG-â, kao društvenoga pokreta i kao akterâ civilnoga društva, u razvoju njihove sposobnosti djelovanja protiv diskriminacije. Glavni je cilj ovoga istraživanja doznati kako antidiskriminacijske agencije u okviru AFEG-â, koje subvencionira država, tumače svoja iskustva i koje implikacije mogu imati subvencije na orijentaciju i smjer njihova djelovanja? Studija ponajprije sadržava intervjue s antidiskriminacijskim odvjetnicima i rukovoditeljima dviju agencija te, također, s predstavnicima pravobranitelja za ravnopravnost. Najveći izazov agencijama predstavlja smanjenje državnih subvencija, što utječe kako na radne uvjete agencija tako i na druge aktivnosti AFEG-â, poput različitih oblika obrazovanja njihovih članica, podizanja svijesti o antidiskriminacijskim pitanjima među različitim službenicima, u općinama, sindikatima i među poslodavcima. Zbog smanjenja subvencija, akteri civilnoga društva poput AFEG-â bili su prisiljeni prilagoditi se načelima tržišta i postati specijalizirani 
poduzetnici, u ovome slučaju na području antidiskriminacijskoga prava. Nadalje, u radu se analiziraju učinci takvoga slijeda događaja kao i mogućnosti suradnje sa sindikatima i pravobraniteljem za ravnopravnost. Iako ta partnerstva otkrivaju asimetričnost odnosâ, zaključuje se o mogućnosti strukturnih otvaranja za širu suradnju AFEG-â, sindikata i pravobranitelja za ravnopravnost.

Ključne riječi: društveni pokret, radna prava, društvena uključenost, migranti, antidiskriminacija, pravobranitelj za ravnopravnost, sindikati 